\title{
Lady and the Trump: Status and Wealth in the Marriage Market*
}

\author{
Johan Almenberg ${ }^{\dagger}$ and Anna Dreber ${ }^{\ddagger}$ \\ Stockholm School of Economics \\ SSE/EFI Working Paper Series in Economics and Finance
}

No. 690

December 4, 2008

\begin{abstract}
We examine a relatively neglected aspect of intergenerational transmission of economic standing, namely culturally determined status markers and their valuation in the marriage market. We take nobility to be such a status marker. Using data on Swedish marriages, we test the hypothesis that nobility have a greater probability of marrying "up" in terms of wealth. We find a large and statistically significant positive effect for nobility. This finding has implications for the intergenerational transmission of inequality, and for the longevity of the institution of nobility itself.
\end{abstract}

JEL classification: D2, D13, J11, J12.

Keywords: Marriage, Status, Intergenerational Transmission, Nobility.

*We thank Tibor Antal, David Cesarini, Robin Douhan, Magnus Henrekson, Henrik Horn, Yannis Ioannides, Magnus Johannesson, Erik Lindqvist, Martin Nowak, Thomas Pfeiffer, Mark Voorneveld, Daniel Waldenström, and seminar participants at the Research Institute of Industrial Economics for helpful comments. Johan Almenberg thanks the Jacob Wallenberg Foundation and the Torsten and Ragnar Söderberg Foundations for financial support, and Johan Almenberg and Anna Dreber thank the Jan Wallander and Tom Hedelius Foundation for financial support. We thank Johanna Chamberlain for research assistance.

${ }^{\dagger}$ Corresponding author. Department of Economics, Stockholm School of Economics, and the Research Institute of Industrial Economics, Stockholm. Email: johan.almenberg@hhs.se

$\ddagger$ Department of Economics, Stockholm School of Economics, and Program for Evolutionary Dynamics, Harvard University. Email: anna.dreber@hhs.se 


\section{INTRODUCTION}

If wealth begets wealth, dynasties may endure even in otherwise meritocratic societies. And if an indicator of past wealth begets wealth, this too will reinforce the persistence of economic standing across generations. Such indicators typically bestow prestige and contribute to high status. Nobility, a culturally determined (i.e., non-genetic) hereditary status marker, might act as such an indicator, and thereby serve as a vehicle for the cultural transmission of economic standing. A wide range of channels besides the traditional economic variables have previously been found to be incorporated in the intergenerational transmission of economic standing. For example, heritability of physical traits such as cognitive ability and health, and physical appearances such as height, attractiveness, and race, have all been found to affect economic outcomes (Bowles and Gintis 2002). While cultural transmission of economic standing clearly also plays a part, this vehicle has so far remained relatively unexplored.

Nobility as an institution is an anachronism: it is a traditional term for the highest social class in some pre-modern societies. Status, however, plays an important role in most societies and in most times, making individuals allocate valuable resources to status-enhancing activities. This suggests that even though nobility no longer entails formal privileges, it may continue to be coveted as a status marker.

Anecdotal evidence suggests that nobility has retained its allure in the modern age. John von Neumann, the mathematician who pioneered the expected utility framework and laid the foundations of modern game theory, was the son of Max Neumann, who in 1913 purchased a claim to Austrian nobility. Max Neumann thereby acquired the right for his offspring (but not for himself) to call themselves von Neumann, a right of which his son John made good use. ${ }^{1}$ Another example is German industrialist Heinrich Thyssen, who married the Hungarian baroness Margit Bornemisza in 1906. Thyssen, a commoner, had his father-in-law adopt him, and since the Baron had no male heirs, Emperor Franz Joseph I bestowed on Thyssen and his descendants the right to adopt the Bornemisza name, coat of arms, and title of Baron. More recently, a scandal erupted in the UK in 2006 following indications of a correlation between individuals making large loans on favorable terms to the Labour party, and subsequent nominations for peerage. $^{2}$

We examine the relative performance of nobility in the marriage market. In doing so, we seek to fuse research on status with research on mating patterns. Our enquiry rests on two implicit assumptions: (1) nobility bestows status on the beholder; and (2) individuals get utility from status, either directly or indirectly. Nobility is typically not traded in open markets, making it difficult to observe its price. We argue that the marriage market might serve as an informal conduit for such transactions. If nobility is a vehicle for the intergenerational transmission of economic standing, the marriage market is the mechanism for this transmission. If such indirect trade occurs, we ought to be able to observe the valuation of nobility in this market.

\footnotetext{
${ }^{1}$ By contrast, von Neumann's contemporary Friedrich von Hayek was bona fide nobility but preferred to omit the von and simply call himself Friedrich Hayek.

${ }^{2}$ These peerages are not hereditary.
} 
The Swedish marriage market provides us with an opportunity to estimate the valuation of nobility as a status asset. In Sweden, nobility as an institution originates from the Alsnö Rules of 1280, which granted landowners exemption from taxation in exchange for supplying the monarch with cavalry troops (vassalage). During the Middle Ages, the link between vassalage and membership of the nobility became weaker. Increasingly, noble titles came to be handed out at the monarch's discretion, and it is these titles that have come to constitute the institution of nobility in its present form. The vast majority of nobility were created in the period 1611-1718, a period of more or less continuous warfare. The last time Sweden entered into war was 1814 . In the ensuing peacetime, the creation of nobility declined rapidly During the 19th century, the monarch's right to hand out noble titles was increasingly questioned. The nobility lost most of their formal privileges in the reform of 1809 , and their political influence was greatly reduced through the reform of 1866, in which the House of Nobility was stripped of its role as upper chamber of Parliament. In 1975, the monarch's right to hand out noble titles was formally revoked. ${ }^{3}$ Today, Swedish nobility enjoy no formal privileges. The power of the king to ennoble was abolished in 1975, and Swedish law does not permit transferring ownership of a claim to nobility in an open market. Marriage is the only remaining conduit for those seeking to join the nobility. In sum, nobility is an asset that conveys no material privilege and cannot be traded in an open market.

An old Swedish custom enables us to identify members of the nobility in our marriage data. Beginning in the mid-16th century, it became customary for newly created nobility to take a new, distinct name upon becoming part of the nobility, often using a familiar set of prefixes and suffixes. ${ }^{4}$ Moreover, Swedish law awards intellectual property rights to surnames in direct relation to how distinct they are, i.e., in inverse proportion to the number of families sharing the name. As a consequence, noble names enjoy particularly strong protection and are easily identifiable. The House of Nobility in Stockholm publishes an annual directory of the members of the approximately 600 remaining noble families. Combining the records of the House of Nobility with the Total Population Register compiled by Statistics Sweden enabled us to generate a unique data set, consisting of repeated cross-sections of all marriages in Sweden in 1985, 1990, 1995, 2000 and 2004. In addition to information about the age, education, income and wealth of both spouses, the data also contains an indicator showing if an individual's surname denotes nobility.

Our data set provides an opportunity to examine whether people are willing to trade wealth for status, by testing the hypothesis that the probability of hypergamy (marrying "up") in terms of wealth increases when an individual belongs to the nobility. If nobility bestows status, and if individuals value both status and material consumption, we would expect an individual belonging to the nobility to attain a premium in the marriage market compared to a non-noble individual with otherwise identical characteristics. Such mating patterns would be consistent

\footnotetext{
${ }^{3}$ At that point, this right had not been exercised in a long time: the last individual to join the ranks of nobility was the explorer Sven Hedin, in 1902.

${ }^{4} \mathrm{~A}$ few noble families bear common names (i.e., names that are not distinct). If there are individuals in our data set that have mistakenly been identified as nobility, this might result in a slight downward bias in our estimates.
} 
with complementarities between wealth and status. In addition, Swedish nobility is hereditary on the male side only.

We also test the auxiliary hypothesis that male nobility is valued more than female nobility. To the extent that individuals care about their offspring, they will attach greater value to a status marker if it can be passed on to their children. Conditional on a continued male lineage, noble status can be thought of as an asset that continues to pay dividends indefinitely. Even with intergenerational discounting, we would expect such an asset to attain a higher price than the non-hereditary equivalent, which can be thought of as an asset paying a dividend only in the current period.

Our main finding is a significant increase in the probability of hypergamy in wealth for members of the nobility, controlling for own wealth and other covariates. This "nobility premium" is sizeable. The wealth distribution in our data is heavily concentrated in the lowest wealth bracket, resulting in a low baseline probability of marrying up. Given this, the observed nobility premium must be considered large, increasing the probability of marrying up by about 40 percent. The effect is statistically significant and robust to a number of different measures of hypergamy.

We find less support for the auxiliary hypothesis that male nobility attain a higher premium than female nobility. The interaction term for male sex and nobility has the expected (positive) sign, but is not statistically significant. In other words, we are unable to reject the hypothesis that the premium is of equal magnitude for male and female nobility.

In sum, our main finding is consistent with the hypothesis that nobility attain a premium on the marriage market, indicating that mate preferences are status sensitive. Our results are highly robust to different definitions of hypergamy. This suggests that the cultural transmission of economic standing, channeled through nobility and other status markers, should be taken into account in an analysis of the intergenerational transmission of inequality.

Our paper is organized as follows. In section 2, we outline some relevant existing research on status and marriage. In section 3 , we describe our marriage data. In section 4 we present our econometric model and report the regression estimates based on the marriage data. We also summarize our robustness checks. We conclude in section 5 , where we discuss some implications of our results and suggest directions for future research.

\section{RELEVANT LITERATURE}

Our analysis draws on two strands of economic research: on the one hand, literature looking at the role of status in the economy, and on the other hand, economic analysis of the "marriage market", i.e., the matching of brides and grooms. In this section we outline some of the more relevant literature in these areas. 


\section{$2.1 \quad$ Status}

That the concern for relative position plays an important role in social interactions is by no means a recent insight in economics. Adam Smith devoted a considerable part of The Theory of Moral Sentiments to a discussion about the link between wealth and social esteem (Smith 2000, see in particular chapters 2 and 3). Veblen (1899, pp. 25-26) famously argued that the pursuit of relative position is the main driving force of (conspicuous) material consumption:

The motive that lies at the root of ownership is emulation; and the same motive of emulation continues active in the further development of the institution to which it has given rise and in the development of all those features of the social structure which this institution of ownership touches. The possession of wealth confers honour; it is an invidious distinction.

This raises the question of whether relative position is pursued as an end in itself. Frank (1999) argues that humans may well be hardwired to seek gratification from moving up in the social hierarchy. He points to research showing that relative position is correlated with serotonin levels in non-human primates (McGuire, Raleigh and Brammer 1982, Raleigh and McGuire 1994).

If individuals derive utility from status in itself, independently of material benefits associated with it, a utility function that incorporates relative position as one of its arguments might do a better job of explaining individual choices (see, e.g., Frank 1985). The idea of status in the utility function has recently been picked up by Becker, Murphy and Werning (2005, p. 283), who note that "[w] hen status is important, individuals would be willing to pay a lot in time, effort, and money for sufficiently high status." Utility derived from relative position in itself has also been analyzed in theoretical work on incentives (see, e.g., Moldovanu, Sela and Shi 2007). A related strand of research takes identity (of which status may be an important determinant) as an argument of the utility function (Akerlof and Kranton, 2000).

To the extent that other individuals attach a value to relative position, status markers may have economic value even to individuals who do not care about relative position in itself. In a laboratory experiment, Ball et al. (2001) find that economic outcomes are affected by the status of participants in a market. Individuals who were assigned high status attained higher prices

as sellers, and lower prices as buyers, than individuals who had been assigned low status. This effect prevailed even when the assignment of status was entirely random, and the randomization process was common knowledge. Such behavioral patterns would allow individuals to reap direct economic benefits from status markers. Hence they may covet these without necessarily getting any utility from the status marker in itself. We return to this important qualifier in section 2.3.

\section{$2.2 \quad$ The marriage market}

We hypothesize that individuals with wealth but no status are likely to be matched in marriage with individuals with status but less wealth. Such a mating pattern is assortative, in the sense 
that individuals are sorted non-randomly into matched pairs on the basis of observable characteristics. Most animals engage in non-random mating. The most commonly observed pattern is positive assortative mating, meaning that a member of a species is matched with another member of that species who is similar with regard to a certain trait. Compared to less stratified mating patterns, positive assortative mating reinforces differences in the endowments of biological, economic and cultural assets in the population over time (Fernández and Rogerson 2001; Fernández, Guner and Rogerson 2005). Under certain assumptions, such mating patterns can preserve heterogeneity in a population indefinitely (Bisin and Verdier 2000).

The seminal microeconomic model of assortative mating in the marriage market is Becker (1973, see also Becker 1991). This model, originally introduced by Koopmans and Beckmann (1957) to describe the assignment of plants to firms, generates a pairwise assignment of elements of one set to elements of another set. The elements of a set differ in a single trait. In Koopmans and Beckmann (1957), an optimal sorting is defined as a sorting that is in the core, in the sense that there is no other coalition outside the core in which both parties could be made better off by an alternative sorting. A key result in this model is that such a sorting necessarily produces the greatest aggregate output (summing across all matches), though it does not necessarily include the largest output element (the matching with the largest output).

Becker's adaptation of the Koopmans and Beckmann model to the marriage market hinges on his characterization of marriage as an economic institution. Central to his analysis is the idea of a marriage production function, which takes the endowments (in a wide sense) of both spouses as its inputs, and produces a joint output that is consumed by the household. This joint output consists of pecuniary rewards from the labor market, non-pecuniary production taking place at home, and leisure. The model is unitary, in the sense that the household is assumed to maximize this output according to a single utility function, which does not require explicit modelling of the bargaining for resources within the household.

In Becker's (1973) model, individuals differ in a single trait, common to both men and women, and a marital output function that is increasing in this trait. The model predicts positive assortative mating in this trait if an increase in the trait for both partners has an effect on marital output that is greater than the sum of the partial effects of increasing one while holding the other constant. In other words, increasing the trait in one partner raises the marginal effect of the other partner's endowment of the trait on marital output. In economic terms, there is complementarity between the two partners' endowments of the trait. In the presence of such complementarity, it can be shown that positive assortative mating produces the greatest aggregate output over all marriages. ${ }^{5}$

Positive assortative mating has been reported in a variety of traits, for both humans and animals. Almenberg and Dreber (2008) show that Swedish marriage data indicate positive assortative mating within both status and wealth. ${ }^{6}$ In the case of mixed matches between wealthy

\footnotetext{
${ }^{5} \mathrm{~A}$ proof is given in the mathematical appendix of Becker (1991, page 130). Note that the model is frictionless, in the sense that the optimal matching is assumed to come about of itself, without any reference to how the process of sorting actually takes place.

${ }^{6}$ There is a large literature on positive assortative mating as well as mate preferences in general. See, for
} 
individuals and individuals with high status, however, the assortative mating is between traits rather than within a trait: individuals with high wealth but low status sorting with individuals with low wealth but high status. To the best of our knowledge, there have been no previous empirical economic examinations of assortative mating between status and wealth in the marriage market.

\section{$2.3 \quad$ Status and marriage}

Economic theory blending the themes of status and marriage is scarce; these areas have typically been examined separately. A notable exception is Mailath and Postlewaite (2006, henceforth $\mathrm{M} \& \mathrm{P})$, who introduce the notion of a "social asset", being an asset that derives some or all of its value from social institutions. They distinguish between the fundamental and intrinsic values of an asset. A status marker that has no fundamental value may still have intrinsic value if it raises expected future income.

While typically non-transferable within a generation, M\&P suggest that certain hereditary traits might have such instrumental value because parents typically care not only about their own consumption but also the consumption of their offspring: while hereditary traits cannot be traded contemporaneously, individuals who don't possess the trait can mate with individuals who do, in the hope that their offspring will inherit it.

The value of hereditary social assets may in part be due to the difficulty of insuring future generations against consumption risk: while any generation may squander a family's economic resources, the subsequent generations can still be endowed with a single asset that cannot be relinquished, and yet raises their expected consumption - namely, a trait that bestows status. In other words, each generation of a lineage can extract the flow value of the asset, but cannot extract the capitalized present value of future flows.

The valuation of such social assets may be self-fulfilling. If everybody else attaches value to an asset, it may become covetable also for individuals to whom it has no intrinsic value. Agents in the $\mathrm{M} \& \mathrm{P}$ model differ in terms of income (which is either high or low) and a binary trait. Income is assumed to be non-storable, so that parents cannot transfer consumption to their offspring. If individuals in possession of the trait are ceteris paribus more desirable partners, they will have a greater chance of marrying "up" in wealth. In this case, acquiring the trait through marriage becomes a means for the parents to insure against some of the consumption risk of their offspring. In other words, the best response of an individual in a society where others seek to marry individuals with the coveted trait may be to also seek to marry individuals with that trait, thereby raising the chances of their offspring having the trait and thereby higher expected income. Hence, in equilibrium the desirability of the trait can self-fulfilling. ${ }^{7}$

The particular characteristics of the attribute are irrelevant: "Any heritable attribute might

example, the references in Almenberg and Dreber (2008).

${ }^{7}$ The offspring have higher expected income for two reasons: income may be correlated with the trait, and possession of the trait raises the likelihood of marrying a high income individual who in turns wants to insure the consumption risk of his/her offspring. The first mechanism is not a necessary requirement. 
serve as a social asset in this way" (Mailath and Postlewaite 2006, p. 1059). Although M\&P do not mention hereditary nobility, this institution fits the prescribed mechanism well. It is widely accepted that broad measures of ability such as IQ are mean-reverting. Noble titles were typically awarded in reward for distinguished service to the monarch. Such services often also resulted in pecuniary rewards, such as land grants. Family fortunes, however, can be lost in the course of a single generation, whereas hereditary nobility is inalienable: it cannot be sold since it cannot be transferred. For an individual with high ability and high income, nobility may have offered a means to insure against lower ability in a subsequent generation, and the associated risk of an inferior economic outcome for the individual's offspring.

\section{MARRIAGE DATA}

To shed more light on the role of nobility in marriage markets, we use a repeated cross-section of all marriages in Sweden during 1985, 1990, 1995, 2000 and 2004, in total 195,405 marriages. ${ }^{8}$ We are interested in the individual probability of marrying up in wealth, hence each spouse is treated as a separate observation, giving us a sample of 380,810 observations. The data are drawn from the Total Population Register, contain every registered marriage during the years in question, and were compiled by Statistics Sweden on our behalf. The data contain information on a number of characteristics of bride and groom, including age, income, net wealth and level of education, all measured at the time of marriage. The data set also contains a dummy variable that takes the value 1 if an individual's surname denotes nobility, and 0 otherwise. A set of names belonging to the remaining families of the nobility was provided by the House of Nobility in Stockholm and used to generate this indicator. In the data set, 1,782 individuals belong to the nobility according to this indicator, equivalent to a bit less than 0.5 percent of the sample. ${ }^{9}$

The control variables are defined in terms of brackets. In part this reflects the requirement from Statistics Sweden to protect individual integrity, given the small number of nobility in our sample. There are five (annual) income categories: [0-121,999], [122,000-199,999], $[200,000-299,999],[300,000-499,999]$, and $[500,000-] .{ }^{10}$ Age is in the following brackets: $(-24]$, [25-29], [30-34], [35-39], [40-44], [45-54], or [55-). The data on education places each individual in one of four categories, corresponding to pre-high school, high school, less than three years of tertiary education, and more than three years of tertiary education. Individual wealth belongs to one of four categories: [0-199,999], [200,000-499,999], [500,000-1,499,999], and [1,500,000-]. There is a high concentration of individuals in the lowest wealth bracket. Summary statistics for the entire sample are reported in Table A.1 in the appendix, and for nobility in Table A 2.

\footnotetext{
${ }^{8}$ At the time of writing, the data for 2005 was not yet available, so we chose the closest available data.

${ }^{9}$ This is slightly larger than the proportion of nobility in the general population (about $0.3 \%$ ). This could be caused by nobility having an above average propensity to marry. Bearing this in mind, we can only make inferences regarding the individuals that actually marry. It could also be caused by sampling error, due to some noble names not being distinct. In this case our estimates will be biased downward, thus underestimating the actual nobility premium.

${ }^{10}$ All amounts reported are nominal and measured in SEK. 1 SEK = approx. 0.1 USD, adjusted for purchasing power.
} 
For each of these covariates, we construct a set of dummy variables corresponding to the aforementioned categories. In the regressions, the lowest bracket is the baseline for each categorical variable.

The wealth tax that was effective in Sweden until 2007 provided strong incentives for tax avoidance. Assets not taxed at all or entered in tax returns at levels below market value included real estate, land holdings, art and antiques, and shares of small-cap firms on the Stockholm stock exchange (not on the A-list). Given that there have been numerous ways of reducing taxable wealth in Sweden, it is unlikely that these figures show the individuals' full wealth. This reduces the efficiency of our estimator. In addition, it is a potential source of unobserved heterogeneity in the sample. Let $W$ be the true wealth, and $(1-\alpha) W$ the observed wealth of individual $i$, with $0<\alpha<1$. If $\alpha$ is positively correlated with belonging to the nobility, our estimate of the nobility premium will be biased upwards. This could make what might in fact be positive assortative mating look like hypergamy. Note that even if $\alpha$ is correlated with nobility, our estimates of the difference in the nobility coefficient between male and female nobility will not be biased unless the correlation itself differs systematically between the sexes. We discuss unobserved heterogeneity more extensively in the next section.

\section{HYPOTHESIS TESTING}

\subsection{From marrying "in" to marrying "up"}

Traditionally, nobility were expected to marry within their own ranks. The marriage market data suggests that this is changing. Endogamy (within-group marriage) still occurs: the odds of a spouse belonging to the nobility are more than twice as high if an individual also belongs to the nobility (logit regression, $\beta_{\text {nobility }}: 1.20 ; p$-value $<0.001$ ). The coefficient on the nobility dummy is large compared to the coefficients on age, income or wealth (see Table A.3. in the Appendix for a full table of the regression results). Yet, the tradition of endogamous marriage seems to be coming to an end. The great majority (98\%) of the nobility in our sample are not married to other nobility, and the number of marriages in which both spouses belong to the nobility declines monotonically over time. Figure 1, below, shows the actual number of endogamous marriages among Swedish nobility observed in our sample, by year. This is plotted against the potential number of such marriages, defined (somewhat arbitrarily) as the minimum of male/female nobility getting married in that year. The third series shows the expected number of such marriages, if nobility were randomly assigned to males and females in our sample. There are two salient features of Figure 1. First, the frequency of endogamous marriage has been steadily declining, despite a more or less constant number of nobility in the marriage market. Second, the rate of endogamous marriage has been converging toward, and recently reached, the level that we would expect to observe with random matching. 
Figure 1.

Endogamous Marriages among Swedish Nobility,1985-2004.

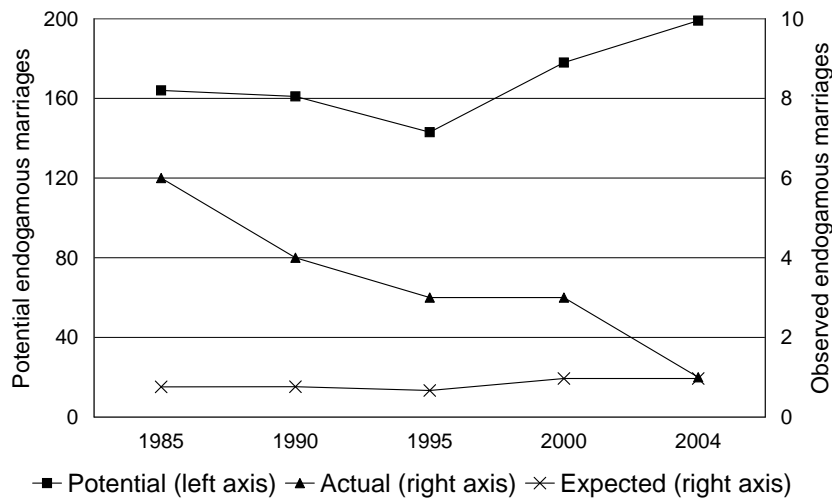

In other words, endogamous marriage within the nobility, once considered the norm, has become an unusual occurrence. ${ }^{11}$ For the most recent observations in our data, such marriages occur at a rate no greater than what we would observe under random matching. One interpretation of this pattern is that nobility, in response to modernizing reforms that curtail their economic influence, turn to exogamy as a dominant strategy for securing access to resources. This process may have gone on for some time: for example, strategic marriages between British nobility, rich in symbolic capital but cash poor, with the daughters of American industrialists in the late 19th and early 20th century have been documented by historians (see, for example, Cannadine, 1990). In Sweden, the waning influence of the nobility in the 20th century was reflected in a marked decline in their statistical overrepresentation on company boards, in the foreign service, and other prestigeous positions (Rundblad 1999). In 1968, individuals belonging to the nobility constituted 12 percent of all board members of the 50 largest companies on the Stockholm stock exchange. By 1998, this had declined to 4 percent. ${ }^{12}$ In the foreign service, nobility constituted 26 percent of all ambassadors and consul generals in 1968. This had declined to 8 percent by 1998 (Rundblad 1999). When the formal privileges of nobility were curtailed, marrying up in wealth may have gained importance as a means of securing access to material resources.

\subsection{Regression analysis: is there a nobility premium?}

Having noted that nobility are not marrying within their group to any great extent, we now turn our attention to whether they are marrying up in wealth. According to our hypothesis, wealthy individuals will covet status markers in general and hereditary, inalienable status marker in particular, resulting in a higher probability of marrying up in wealth for individuals belonging to the nobility. To test this hypothesis, we construct an indicator variable that takes on the

\footnotetext{
${ }^{11}$ By contrast, Banerjee et al. (2008) report that within-caste marriage is still prevalent in India.

${ }^{12}$ As measured by turnover (Rundblad 1999).
} 
value 1 if individual $i$ marries into a higher wealth bracket, and 0 otherwise. To examine the robustness of our results, we test a number of different specifications of this indicator, including the transition probabilities between specific wealth brackets. Our results are broadly robust to such modifications.

We use the logistic binary response model (logit regression) to estimate the probability of an individual marrying a spouse in a higher wealth bracket. The logistic functional form generates estimates that are bounded on the unit interval, and hence has an intuitive appeal when the dependent variable is a binary outcome.

We regress a dummy variable that indicates marrying up on an individuals age, education, income, wealth, and sex, as well as whether the individual belongs to the nobility. ${ }^{13}$ We have no reason to believe that the parameters of the true model are the same for men and women. For this reason, we run separate regression for women and men. Since we are also interested in how the nobility coefficient differs between the sexes, we also run a joint regression where we allow all coefficients to differ between the sexes. We include a dummy variable indicating whether the individual is male, allowing for different baseline probabilities for men and women, and interaction terms between the male dummy and the controls, including the nobility dummy, thus allowing for the slope coefficients to differ between the sexes.

The joint regression offers a statistical measure of how the nobility coefficient differs between the sexes. A Wald test rejects that these interaction terms are jointly insignificant (p-value $<0.0001$ ). In each regression, we also include a full set of controls for the spouse, to make sure that we are not confounding an increased probability of marrying up in wealth with an increased probability of marrying somebody with higher age, income or education. Note that in order to run a joint regression, we rearrange the observations so that each individual appears twice, once as individual $i$ and once as a spouse. This allows us to estimate the probability on the whole population of individuals in the sample. For the regression on the joint sample, where we allow the coefficients to differ between the sexes, we can write our regression specification as a logistic probability model of the form

$$
P\left(Y_{i j}=1 \mid \mathbf{X}_{i j}\right)=1 /\left(1+e^{-\left(\alpha_{j}+\mathbf{X}_{i j} \boldsymbol{\beta}_{j}+\delta_{j} \text { Nobility }_{i}\right)}\right)
$$

where $P\left(Y_{i j}=1 \mid \mathbf{X}_{i j}\right)$ denotes the probability of marrying up for an individual $i$ of sex $j$, conditional on the covariates. Nobility is a dummy variable that takes on the value 1 if individual $i$ belongs to the nobility, and $\mathbf{X}_{i}$ is the vector of controls mentioned above. The subscript $j$ denotes gender. Table 1 summarizes the results from the regressions, for both sexes separately (columns 1 and 2), and for the joint sample (column 3).

\footnotetext{
${ }^{13}$ Since individuals in the highest wealth bracket cannot marry up, we exclude these observations from the analysis. In our main regression, we do not control for the spouse belonging to the nobility. Our results are robust to the inclusion of this control. They are also robust to omitting all spouse controls.
} 
Table 1

Dependent Variable: Marrying "Up" in Wealth.

\begin{tabular}{lccc}
\hline & $\begin{array}{c}\text { Women } \\
(1)\end{array}$ & $\begin{array}{c}\text { Men } \\
(2)\end{array}$ & $\begin{array}{c}\text { All } \\
(3)\end{array}$ \\
\hline Nobility & 0.390 & 0.434 & 0.382 \\
& $(0.021)^{* *}$ & $(0.031)^{* *}$ & $(0.024)^{* *}$ \\
Male* Nobility & & & 0.055 \\
& & & -0.834 \\
Additional Controls & Yes & Yes & Yes \\
Interaction terms $(*$ male) & No & No & Yes \\
Male & & & -0.473 \\
& & & $(0.000)^{* * *}$ \\
Constant & -5.129 & -5.517 & -4.919 \\
& $(0.000)^{* * *}$ & $(0.000)^{* * *}$ & $(0.000)^{* * *}$ \\
\hline$N$ & 171187 & 170464 & 341651 \\
$\mathrm{R}^{2} /$ Pseudo-R & & 0.146 \\
\hline \hline Robust standard errors. $p$-values in parentheses & & \\
$*$ significant at $10 \% ; *$ significant at $5 \% ; * *$ significant at $1 \%$ &
\end{tabular}

The coefficient for nobility is positive and statistically significant in all specifications. Columns 1 and 2 show that both male and female nobility have higher probabilities of marrying up in wealth, when controlling for the available covariates. The coefficient is larger for noble men than for noble women. Column 3 shows the same thing, but the difference is not statistically significant. We rely on the specification in column (3) of Table 1 as our main model, and interpret our results below. A complete table of coefficients for these regressions can be found in Table A.4. in the Appendix.

The observed nobility premium is sizeable. The wealth distribution in our sample is heavily concentrated in the lowest bracket. When an individual marries up, his/her spouse by definition marries down. Hence, the largest potential number of marriages in which one individual marries up in wealth equals the number of individuals in the second, third and fourth wealth brackets, about $3.2 \%$ of the sample. As a result, marrying up in wealth is a rare event, achieved by only $2.6 \%$ of the individuals in our sample. For nobility, however, this frequency is $4.4 \%$. What our regressions show is that including a number of relevant controls does not diminish this nobility premium. In the main regression (Table 1, column 3), the estimated nobility premium is an almost 40 percent increase in the odds of marrying into a higher wealth bracket.

While the interaction term between nobility and being male has the expected (positive) sign in the logit regression in column 3 , it is not statistically significant. This implies that we cannot reject that the increase in probability is of the same magnitude for noble men and noble women. Thus, we do not find conclusive support for our auxiliary hypothesis of a gender gap in the nobility premium. ${ }^{14}$

\footnotetext{
${ }^{14}$ We also estimate a linear (OLS) model using the same specification. With this functional form, the interaction term between male sex and nobility has the wrong sign, and is still not statistically significant. Because the $\mathrm{R}^{2}$
} 
Nobility might be correlated with variables that we are unable to control for in the sample, for example human and social capital, or even physical appearance. If such unobserved heterogeneity is a direct consequence of nobility, this does not undermine the validity of our findings. It is important to recognize, however, that there might be other unobserved variables that could arguably affect our results. This is a further reason for interpreting our results with some caution. Nobility are slightly over-represented among individuals that marry, implying that there might be some selection bias. Moreover, if the fraction of an individual's wealth that goes unreported is positively correlated with belonging to the nobility, then our estimates will be biased upward. Table A.2.2. in the Appendix shows that nobility are "to the right" of the general sample in terms of wealth distribution. Nobility may have wealthier parents than other individuals in the same wealth bracket. An individual marrying a member of the nobility with no wealth could be expecting future wealth through inheritance. Another possible omitted variable would be that past wealth is positively correlated with residing in affluent neighbourhoods, and residing in affluent neighbourhoods may be positively correlated with the probability of marrying "up".

A more sophisticated modelling approach to the marriage market would add additional complexity to the interpretation of our results. Hypothetically, nobility could be more prevalent in marriage markets in which population densities, the fraction of singles, and sex ratios among singles differ from the population average. In a search model of the marriage market, these factors would be expected to influence the reservation price at which a match is made (Drewianka 2003). Controlling for such factors is beyond the scope of our data set, but would constitute an interesting avenue for further research.

While each of these concerns are valid, they affect only the interpretation of our findings, and not their implications. Regardless of whether nobility marry up in wealth because their nobility is a covetable status marker or because they live in affluent neighborhoods etc., the consequence of this hypergamy is that economic resources are channeled toward nobility at a time when they have relinquished all other economic and political privileges. To the extent that access to resources is linked to reproductive success, this may have considerable implications for the longevity of nobility as an institution and for the intergenerational transmission of inequality.

\subsection{Robustness checks}

We conduct a number of robustness checks to test the validity of our results. Our conclusion, based on these checks, is that our results are robust. A non-technical summary of the robustness checks follows below.

Our first robustness check consists of examining whether our main finding, the nobility premium, is consistent with alternative measures of hypergamy. The measure we use for our main regression, reported in Table 1 above, is the probability of marrying an individual in a higher wealth category. Let $x_{i}, y_{i}$ denote the wealth bracket of individual $i$ and individual $i$ 's spouse.

of the linear model is considerably lower than for the logistic model, we focus mainly on the latter. Estimates for the linear model are included in Table A.4., in the Appendix. 
Our main model corresponds to estimating the probability of $y_{i}>x_{i}$, conditional on the covariates. To check the robustness of our findings, we use the same model specification, except that we use three other measures of hypergamy: (1) $x_{i}=1, y_{i} \geq 2 ;(2) x_{i} \leq 2, y_{i}>2$; and (3) $x_{i}=1, y_{i}=4$. We find evidence of a nobility premium of similar magnitude in all the aforementioned cases, suggesting that our results are not particularly sensitive to the choice of hypergamy measure. Coefficients and $p$-values for the nobility dummy are shown in Table 2, below.

Table 2

Robustness Checks.

\begin{tabular}{|c|c|c|}
\hline \multirow[b]{2}{*}{ Measure of hypergamy } & \multicolumn{2}{|c|}{ Nobility dummy } \\
\hline & Coefficient & p-value \\
\hline $\mathrm{xi}_{\mathrm{i}}=1, \mathrm{yi}_{\mathrm{i}}>1$ & 0.499 & $(0.003)^{* * *}$ \\
\hline $\mathrm{x}_{\mathrm{i}}<3, \mathrm{yi}_{\mathrm{i}}>2$ & 0.400 & $(0.077)^{*}$ \\
\hline$x_{i}=1, y_{i}=4$ & 0.862 & $(0.003) * * *$ \\
\hline
\end{tabular}

A second purpose of these checks is to examine whether our results are driven by differences in the distribution of nobility and non-nobility within wealth brackets. The wealth distributions of the nobility and of the general sample are different, with the probability mass of the former being "to the right" of the latter, in the sense of stochastic first order dominance. Given the high level of aggregation - only four wealth brackets - differences in the distribution within each bracket might influence our results. If, for example, the average wealth of nobility in the lowest wealth bracket is higher (lower) than average wealth of non-nobility in the same bracket, our estimate for this group would be biased upward (downward). As an additional precaution, we also estimate the probability of marrying "down". We run a regression similar to the one above, except that the dependent variable is a dummy variable indicating whether an individual from the second, third or fourth wealth bracket marries an individual in a lower wealth bracket, $x_{i}>y_{i}$. ${ }^{15}$ If nobility in the higher wealth brackets on average have higher wealth than other individuals within that bracket, then they should be less likely to marry down. We find no evidence of such an effect (nobility dummy $p$-value $<0.971$ ). We conclude that our results are not likely to be driven by differences in the distribution of nobility and non-nobility within wealth brackets.

\section{CONCLUSION}

We have attempted to fuse the research on status with that on mating patterns, by examining the relative performance of hereditary nobility, a proxy for status, in the marriage market. In

\footnotetext{
${ }^{15}$ Note that this regression is, in practice, not perfectly symmetrical with a regression looking at the probability of marrying up. The former omits individuals in the lowest wealth bracket, who by definition can't marry down. The latter omits individuals in the highest wealth bracket, who by definition can't marry up.
} 
Sweden, nobility no longer enjoy formal privileges, yet anecdotal evidence suggests that nobility remains coveted. Since nobility is not traded in open markets, we study the marriage market as a conduit for such transactions.

We find that nobility enjoy a higher probability of marrying up in wealth. Because our sample is heavily concentrated in the lowest wealth bracket, we observe few individuals marrying up in wealth. For the general sample, the rate is $2.6 \%$. For the subsample belonging to the nobility, however, this rate is $4.4 \%$. We have shown that this apparent nobility premium is robust to controlling for a number of relevant variables.

The data also indicates a gender difference, with males, for whom nobility is heriditary, attaining a higher premium. The gender difference, however, is not statistically significant. Taken together, these two results could be explained in several ways. To suggest a few: (1) There is a nobility premium, and it is higher for males. The sample contains enough individuals belonging to the nobility to detect the premium, but not enough to identify the gender difference. (2) There is a nobility premium, and it is higher for males. Other gender differences in mate preferences obscure the gender difference in the nobility premium. (3) There is a nobility premium, because individuals care about their own status, but no gender difference, because individuals do not care about their children's status. ${ }^{16}$ (4) There is no nobility premium. The observed effect is driven by unobserved heterogeneity.

Our data does not enable us to discern which, if any, of these alternative explanations is the correct one. Hypothesis testing on our sample of observational data rejects the null hypothesis that nobility do not have better chances of marrying up in wealth. The data has clear limitations, and we are not able to rule out concerns about unobserved heterogeneity - as is always the case with observational data. We wish to emphasize that the results presented here are a first step toward a better understanding of the nobility premium, and we encourage other researchers to shed more light on this topic. We will conclude by discussing some possible implications of a nobility premium.

Who marries whom influences future generations to the extent that the characteristics of the parents are passed on to their children, through their genes as well as a shared environment. Who marries whom is therefore an indicator of the distribution of a wide range of characteristics of successive generations. In a similar manner, the distribution of culturally determined status markers in the population may have important effects on economic outcomes.

In an era when their formal privileges have been curtailed, a marriage premium for nobility suggests a positive valuation of the status marker itself. If the symbolic capital of nobility continues to attract a premium in the marriage market, this provides an additional mechanism that reinforces the persistence of social stratification and inequality. Moreover, if status and consumption of other goods are complementary as Becker, Murphy and Werning (2005) suggest, and if status markets are becoming relatively more scarce, the nobility premium might well be

\footnotetext{
${ }^{16}$ This would contradict the assumptions of the model in Mailath and Postlewaite (2006). It would also contradict the large literature on bequest motives.
} 
increasing over time. ${ }^{17}$

If access to material resources is correlated with greater reproductive success, a marriage market premium would imply that nobility may persist for a long time, even if no new nobility is created. Historically, male nobility, and rich men in general, have reproduced to a greater extent than other men (e.g., Clark 2007). This is not surprising given that these men tended to be in the upper strata of wealth and status, and had privileges held by neither commoners nor noble women. Wealth and status have both been found to correlate positively with male reproductive success among other groups, such as 19th Century Mormons (Mealey 1985) and the Ifaluk in Micronesia (Turke and Betzig 1985).

When nobility is only passed on through male offspring, the perpetuation of nobility requires a continued male lineage. We merged data in Fahlbeck (1899) with 20th Century records from the House of Nobility in order to trace the evolution of the stock of noble families over time. ${ }^{18}$ Note that the number of families is the observed quantity, and has not been corrected for population size. ${ }^{19}$ Figure 2 shows the evolution of the stock of noble families since 1500 . The net stock is the difference between the cumulative created and the cumulative discontinued.

Figure 2.

The Evolution of Swedish Nobility Since 1500.

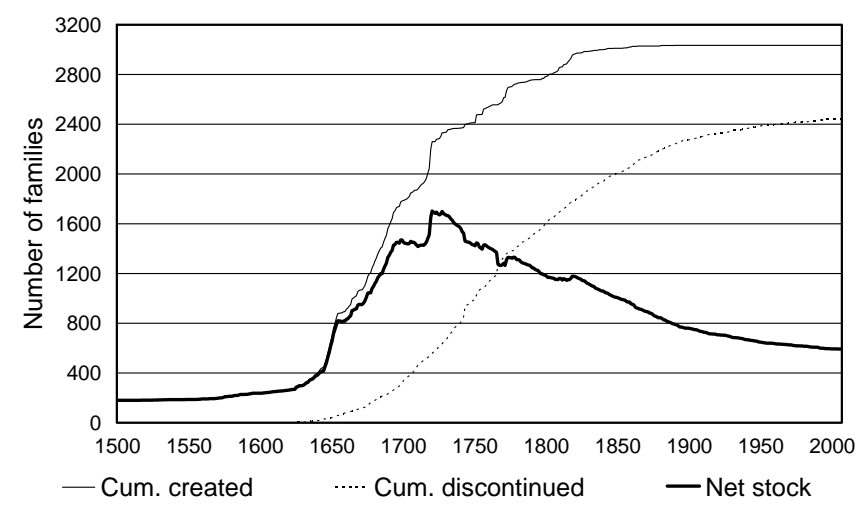

A rapid decline in the creation rate has caused the stock of nobility to decline monotonically in the last 200 years (i.e., in peacetime). The recent decline is well described by a simple model of

\footnotetext{
${ }^{17}$ Becker, Murphy and Werning (2005) show how the price of status relative to other consumption goods increases when status markers become relatively more scarce.

${ }^{18}$ These records are as yet incomplete: while it is generally known if a male lineage has been discontinued, it is not always known in which year this happened. In the cases where the decade, but not exact year, was known, we used the middle year of that decade. In the cases where not even the decade was known, the discontinuation year was imputed using linear regression. The discontinuation year was imputed using information on year of creation, monarch at time of creation, and the occupation of the first member of the noble lineage. Approximately 10 percent of all discontinuation dates were imputed in this manner.

${ }^{19}$ The analysis is made slightly more complicated by the fact that the dataset includes families that were raised from the lower ranks of nobility to the higher, titled ranks. This applies to about 20 percent of the sample. The branch that was elevated to a higher rank is counted in the data as the creation of a new noble family, which overlooks the fact that it stems from a male lineage that is already noble. Excluding this subset, however, has negligable effects on the general picture.
} 
exponential decline. When fitting such a model to this data, we get a predicted half-life of about 100 years for the stock of nobility ${ }^{20}$ There are currently almost 600 remaining noble families. If the stock continues to decline at this rate, there will remain about 300 families by the year 2100 , 150 families by the year 2200, and so forth. In sum, nobility as an institution appears to have considerable longevity, despite no longer enjoying economic or political privileges. If this simple model above comes close to predicting future developments, we ought to conclude that simply ceasing to create new noble families is not a very effective way of terminating the institution of nobility. ${ }^{21}$

Hereditary nobility is an anachronism. Our analysis can be extended, however, to other hereditary status markers which may perpetuate in modern times. For example, many Ivy League universities have adopted a so called "legacy policy", whereby the probability of acceptance is higher, ceteris paribus, if a parent has attended the same university (Karabel 2005). To the extent that an Ivy League education is a positional good, alumni status might come to play a similar role in marriage markets in the future. We encourage future research in this area.

In sum, status affects economic outcomes, and is positively assorted with wealth in the marriage market. Given the hereditary nature of nobility, this mating pattern has consequences for the transmission of inequality. Not only does wealth beget wealth in the marriage market, but an indicator of past wealth does so, too. We end our discussion by noting that the marriage of wealth and status is an old and familiar theme. Well known representations in popular culture include Hogarth's Marriage à la Mode, a series of 19th century engravings featuring a cash poor aristocrat, Lord Squanderfield, who marries off his son to the daughter of a merchant. In di Lampedusa's (1966) novel The Leopard, Don Fabrizio, an ageing Sicilian prince, reluctantly marries off his orphaned nephew to the daughter of a local businessman with new-found wealth but no pedigree. In a revealing episode, Don Fabrizio is told that the prospective bride's grandfather Peppe was known, unflatteringly, as "Peppe 'Mmerda". The prince is taken aback by this information, but is determined to press ahead with matters. Non olet, he reminds himself, non olet. $^{22}$

\footnotetext{
${ }^{20}$ Let $S(t)$ denote the stock of noble families at time $t$, normalized by population size. From a regression of $\log (S)$ on the time interval since 1900 , we get a time coefficient of -0.0079 (OLS with robust standard errors, $p$ value $<0.001, R$-squared 0.986$)$. Entering this estimate into the model of exponential decline we get an expression for the evolution of the stock of nobility over time:

$$
S(t)=S_{0} e^{-0.0079(t-1900)}
$$

${ }^{21}$ This reasoning assumes no frequency-dependent advantage. If, for example, the marriage market valuation of nobility is an increasing function of the scarcity of nobility, a frequency-dependent nobility premium might arise. This would imply far greater longevity for nobility than is predicted by our exponential model. Exploring the ramifications of this more fully would constitute an exciting avenue for future research. It should also be noted that since no new noble lineages are created, the institution is likely to eventually cease to exist, although this might take a very long time. In stochastic models of population dynamics, lineages are typically either eliminated or go to fixation (so that the entire population stems from the same lineage). In the case of nobility, both outcomes would make the institution redundant.

${ }^{22}$ (Latin) Pecunia non olet: money does not smell.
} 


\section{REFERENCES}

Akerlof, George A. and Rachel E. Kranton (2000). Economics and Identity, Quarterly Journal of Economics 115: 715-753.

Almenberg, Johan and Anna Dreber (2008) Assortative Mating in Age, Education, Income and Wealth. Sweden 1985-2004, Mimeo, Stockholm School of Economics.

Ball, Sheryl, Catherine Eckel, Philip J. Grossman and William Zame (2001) Status in Markets, Quarterly Journal of Economics.116: 161-181.

Banerjee, Abhijit, Esther Duflo, Maitreesh Ghatak and Jeanne Lafortune (2008). Marry for what? Caste and Mate Selection in Modern India, Mimeo, Massachusetts Institute of Technology.

Becker, Gary S. (1973). A Theory of Marriage: Part 1, Journal of Political Economy. 81: $813-846$.

Becker, Gary S. (1991) A Treatise on the Family. Cambridge (Mass.): Harvard University Press.

Becker, Gary S., Kevin M. Murphy and Ivan Werning (2005). The Equilibrium Distribution of Income and the Market for Status, Journal of Political Economy. 113: 282-310.

Bisin, Alberto and Thierry A. Verdier (2000). Beyond the Melting Pot: Cultural Transmission, Marriage, and the Evolution of Ethnic and Religious Traits, Quarterly Journal of Economics. 115: $955-988$.

Bowles, Samuel and Herbert Gintis (2002). The Inheritance of Inequality, Journal of Economic Perspectives. 16: 3-30.

Cannadine, David (1990). The Decline and Fall of the British Aristocracy. New Haven: Yale University Press.

Clark, Gregory (2007). A Farewell to Alms. A Brief Economic History of the World. Princeton: Princeton University Press.

Drewianka, Scott (2003). Estimating Social Effects in Matching Markets: Externalities in Spousal Search, Review of Economics and Statistics. 85: 409-423.

Fahlbeck, Pontus E. (1898). Sveriges Adel. Lund: Gleerups.

Fernández, Raquel and Richard Rogerson (2001). Sorting and Long-Run Inequality, Quarterly Journal of Economics. 116: 1305-1341. 
Fernández, Raquel, Nezih Guner and Richard Rogerson (2005). Love and Money: A Theoretical and Empirical Analysis of Household Sorting and Inequality, Quarterly Journal of Economics. 120: $273-344$.

Frank, Robert H. (1985). The Demand for Unobservable and Other Positional Goods. American Economic Review. 75: 101-116.

Frank, Robert H. (1999). Luxury Fever. New York: Free Press.

Koopmans, Tjalling C. and Martin J. Beckmann (1957). Assignment Problems and the Location of Economics Activity, Econometrica. 25: 53-76.

Karabel, Jerome (2005). The Chosen. New York: Mariner Books.

Kremer, Michael (1997). How Much Does Sorting Increase Inequality?, Quarterly Journal of Economics. 112: 115-139.

di Lampedusa, Giuseppe T. (1966). The Leopard. New York: Pantheon.

Mailath, George J. and Andrew Postlewaite (2006). Social Assets, International Economic Review. 47: 1057-1091.

McGuire, Michael T., Michael J. Raleigh and Gary Brammer (1982). Sociopharmacology, Annual Review of Pharmacological Toxicology. 22: 643-661.

Mealy, Linda (1985). The Relationship Between Social Status and Biological Success: A Case Study of the Mormon Religious Hierarchy, Ethology and Sociobiology. 6: 249-257.

Moldovanu, Benny, Aner Sela and Xianwen Shi (2007). Contests for Status, Journal of Political Economy. 115: 338-363.

Raleigh, Michael J. and Michael T. McGuire (1994). Seratonin, Aggression, and Violence in Vervet Monkeys, in: Roger Masters and Michael T McGuire (eds.), The Neurotransmitter Revolution: Seratonin, Social Behavior, and the Law. Carbondale: Southern Illinois University Press.

Rundblad, Lili-Anne (1999). Adliga strategier. Master's thesis, Department of Economic History, Stockholm University.

Smith, Adam (2000). The Theory of Moral Sentiments. Amherst: Prometheus.

Turke, Paul W. and Laura L. Betzig (1985). Those Who Can Do: Wealth, Status, and Reproductive Success on Ifaluk, Ethology and Sociobiology. 6: 79-87.

Veblen, Thorstein (1899). The Theory of the Leisure Class: An Economic Study of Institutions. New York: Macmillan. 


\section{Appendix}

Table A.1. Summary Statistics for the Entire Sample

A.1.1. Age Distribution by Gender, in Percent.

\begin{tabular}{llllllll}
\hline \hline & \multicolumn{7}{c}{ Age } \\
\hline & -25 & $25-29$ & $30-34$ & $35-39$ & $40-44$ & $45-54$ & $55-$ \\
Men & 9.4 & 27.6 & 25.4 & 14.9 & 8.4 & 9.4 & 4.8 \\
Women & 19.6 & 31.2 & 21.0 & 11.5 & 6.7 & 7.4 & 2.6 \\
All & 14.6 & 29.4 & 23.2 & 13.2 & 7.6 & 8.4 & 3.7 \\
\hline
\end{tabular}

A.1.2. Education Distribution by Gender, in Percent.

\begin{tabular}{lllll}
\hline \hline & & \multicolumn{3}{c}{ Education } \\
\hline & $<$ High school & High school & $<3$ years tertiary & $>3$ years tertiary \\
Men & 18.2 & 49.4 & 14.8 & 17.5 \\
Women & 16.1 & 49.6 & 16.4 & 18.0 \\
All & 17.1 & 49.5 & 15.6 & 17.8 \\
\hline
\end{tabular}

A.1.3. Income Distribution by Gender, in Percent.

\begin{tabular}{llllll}
\hline \hline \multicolumn{5}{c}{ Income } \\
\hline & {$[-121,999]$} & {$[122,000-$} & {$[200,000-$} & {$[300,000-$} & {$[500,000-]$} \\
Men & 27.9 & $199,999]$ & $299,999]$ & $499,999]$ & \\
Women & 49.2 & 28.0 & 26.9 & 13.8 & 3.3 \\
All & 38.9 & 29.6 & 15.0 & 4.2 & 0.6 \\
\hline
\end{tabular}

A.1.4. Wealth Distribution by Gender, in Percent.

\begin{tabular}{lllll}
\hline \hline & & \multicolumn{3}{c}{ Wealth } \\
\hline & {$[-200,000]$} & {$[200,000-$} & {$[500,000-$} & {$[1,500,000-]$} \\
Men & 96.1 & $499,999]$ & $1,499,999]$ & \\
Women & 97.5 & 2.1 & 1.1 & 0.8 \\
All & 96.8 & 1.6 & 0.5 & 0.3 \\
\hline
\end{tabular}


Table A.2. Summary Statistics for Nobility Only A.2.1. Age Distribution by Gender, in Percent.

\begin{tabular}{llllllll}
\hline \hline & & \multicolumn{7}{c}{ Age } \\
\hline & -25 & $25-29$ & $30-34$ & $35-39$ & $40-44$ & $45-54$ & $55-$ \\
Men & 5.9 & 26.5 & 26.9 & 16.0 & 7.7 & 11.0 & 6.1 \\
Women & 11.2 & 33.4 & 23.9 & 10.4 & 8.8 & 8.6 & 3.7 \\
All & 8.4 & 29.7 & 25.5 & 13.4 & 8.2 & 9.9 & 4.9 \\
\hline
\end{tabular}

A.2.2. Education Distribution by Gender, in Percent.

\begin{tabular}{lllll}
\hline \hline & \multicolumn{3}{c}{ Education } \\
\hline & $<$ High school & High school & $<3$ years tertiary & $>3$ years tertiary \\
Men & 11.5 & 40.0 & 17.0 & 31.5 \\
Women & 10.7 & 41.2 & 19.5 & 28.6 \\
All & 11.1 & 40.6 & 18.2 & 30.1 \\
\hline
\end{tabular}

A.2.3. Income Distribution by Gender, in Percent.

\begin{tabular}{llllll}
\hline \hline \multicolumn{5}{c}{ Income } \\
\hline & {$[-121,999]$} & {$[122,000-$} & {$[200,000-$} & {$[300,000-$} & {$[500,000-]$} \\
Men & 23.8 & $199,999]$ & $299,999]$ & $499,999]$ & \\
Women & 42.2 & 25.0 & 27.2 & 19.0 & 5.0 \\
All & 32.6 & 29.3 & 19.9 & 7.5 & 1.1 \\
\hline
\end{tabular}

A.2.4. Wealth Distribution by Gender, in Percent.

\begin{tabular}{lllll}
\hline \hline & & \multicolumn{3}{c}{ Wealth } \\
\hline & {$[-200,000]$} & {$[200,000-$} & {$[500,000-$} & {$[1,500,000-]$} \\
Men & 87.7 & $499,999]$ & $1,499,999]$ & \\
Women & 92.3 & 4.6 & 3.1 & 4.6 \\
All & 89.9 & 2.7 & 3.0 & 2.0 \\
\hline
\end{tabular}


Table A.3. Dependent Variable: Probability of Spouse Belonging to the Nobility.

\begin{tabular}{|c|c|}
\hline & Logit \\
\hline Nobility & $\begin{array}{c}1.197 \\
(0.000)^{* * *}\end{array}$ \\
\hline \multicolumn{2}{|l|}{ Age } \\
\hline $25-29$ & $\begin{array}{c}0.157 \\
(0.112)\end{array}$ \\
\hline $30-34$ & $\begin{array}{c}0.148 \\
(0.181)\end{array}$ \\
\hline $35-39$ & $\begin{array}{c}0.101 \\
(0.438)\end{array}$ \\
\hline $40-44$ & $\begin{array}{c}0.089 \\
(0.558)\end{array}$ \\
\hline $45-54$ & $\begin{array}{c}0.121 \\
(0.445)\end{array}$ \\
\hline $55-$ & $\begin{array}{c}0.143 \\
(0.448)\end{array}$ \\
\hline Education & \\
\hline High school & $\begin{array}{c}0.19 \\
(0.026)^{* *}\end{array}$ \\
\hline$<3$ years tertiary & $\begin{array}{c}0.255 \\
(0.011)^{* *}\end{array}$ \\
\hline$>3$ years tertiary & $\begin{array}{c}0.384 \\
(0.000)^{* * *}\end{array}$ \\
\hline Income & \\
\hline$[122,000-199,999]$ & $\begin{array}{l}-0.076 \\
(0.284)\end{array}$ \\
\hline$[200,000-299,999]$ & $\begin{array}{c}-0.163 \\
(0.057)^{*}\end{array}$ \\
\hline$[300,000-499,999]$ & $\begin{array}{c}0.106 \\
(0-298)\end{array}$ \\
\hline$[500,000-]$ & $\begin{array}{c}0.38 \\
(0.014)^{* *}\end{array}$ \\
\hline Wealth & \\
\hline$[200,000-499,999]$ & $\begin{array}{c}0.104 \\
(0.528)\end{array}$ \\
\hline$[500,000-1,499,999]$ & $\begin{array}{c}0.009 \\
(0.968)\end{array}$ \\
\hline $1,500,000$ & $\begin{array}{c}0.577 \\
(0.004) * * *\end{array}$ \\
\hline
\end{tabular}

Continued on the next page 
Continued from the previous page

\begin{tabular}{|c|c|}
\hline \multicolumn{2}{|l|}{ Spouse } \\
\hline \multicolumn{2}{|l|}{ Age } \\
\hline $25-29$ & $\begin{array}{c}0.214 \\
(0.038)^{* *}\end{array}$ \\
\hline $30-34$ & $\begin{array}{c}0.241 \\
(0.035)^{* *}\end{array}$ \\
\hline $35-39$ & $\begin{array}{c}0.184 \\
(0.165)\end{array}$ \\
\hline $40-44$ & $\begin{array}{c}0.276 \\
(0.072)^{*}\end{array}$ \\
\hline $45-54$ & $\begin{array}{c}0.33 \\
(0.042)^{* *}\end{array}$ \\
\hline $55-$ & $\begin{array}{c}0.349 \\
(0.089)^{*}\end{array}$ \\
\hline \multicolumn{2}{|l|}{ Education } \\
\hline High school & $\begin{array}{c}0.214 \\
(0.015)^{* *}\end{array}$ \\
\hline$<3$ years tertiary & $\begin{array}{c}0.457 \\
(0.000)^{* * *}\end{array}$ \\
\hline$>3$ years tertiary & $\begin{array}{c}0.694 \\
(0.000)^{* * *}\end{array}$ \\
\hline \multicolumn{2}{|l|}{ Income } \\
\hline$[122,000-199,999]$ & $\begin{array}{c}-0.08 \\
(0.279)\end{array}$ \\
\hline$[200,000-299,999]$ & $\begin{array}{c}0.023 \\
(0.781)\end{array}$ \\
\hline$[300,000-499,999]$ & $\begin{array}{c}0.084 \\
(0.422)\end{array}$ \\
\hline$[500,000-]$ & $\begin{array}{l}-0.222 \\
(0.195)\end{array}$ \\
\hline \multicolumn{2}{|l|}{ Wealth } \\
\hline$[200,000-499,999]$ & $\begin{array}{c}0.399 \\
(0.010)^{* *}\end{array}$ \\
\hline$[500,000-1,499,999]$ & $\begin{array}{c}1.123 \\
(0.000)^{* * *}\end{array}$ \\
\hline $1,500,000-$ & $\begin{array}{c}1.608 \\
(0.000)^{* * *}\end{array}$ \\
\hline
\end{tabular}

Continued on the next page 
Continued from the previous page

\begin{tabular}{|c|c|}
\hline Year & \\
\hline 1990 & $\begin{array}{l}-0.092 \\
(0.313)\end{array}$ \\
\hline 1995 & $\begin{array}{l}-0.053 \\
(0.589)\end{array}$ \\
\hline 2000 & $\begin{array}{l}-0.101 \\
(0.304)\end{array}$ \\
\hline 2004 & $\begin{array}{c}-0.212 \\
(0.039) * *\end{array}$ \\
\hline Male & $\begin{array}{c}-0.14 \\
(0.027)^{* *}\end{array}$ \\
\hline Constant & $\begin{array}{c}-6.091 \\
(0.000)^{* * *} \\
\end{array}$ \\
\hline$N$ & 343,540 \\
\hline $\mathrm{R}^{2} /$ Pseudo- $\mathrm{R}^{2}$ & 0.023 \\
\hline
\end{tabular}


Table A.4. Dependent Variable: Marrying "Up" in Wealth.

\begin{tabular}{|c|c|c|c|c|}
\hline & \multicolumn{3}{|c|}{ Logit } & \multirow{2}{*}{$\begin{array}{c}\text { OLS } \\
(4)\end{array}$} \\
\hline & (1) & $(2)$ & (3) & \\
\hline & Women & Men & All & All \\
\hline \multirow[t]{2}{*}{ Nobility } & 0.39 & 0.434 & 0.382 & 0.018 \\
\hline & $(0.021)^{* *}$ & $(0.031)^{* *}$ & $(0.024) * *$ & $(0.035)^{* *}$ \\
\hline \multirow{2}{*}{ Male Nobility } & & & 0.055 & -0.008 \\
\hline & & & $(0.834)$ & $(0.447)$ \\
\hline \multicolumn{5}{|l|}{ Age } \\
\hline \multirow[t]{2}{*}{$25-29$} & 0.14 & 0.51 & 0.211 & 0.003 \\
\hline & $(0.016)^{* *}$ & $(0.000)^{* * *}$ & $(0.000)^{* * *}$ & $(0.007)^{* * *}$ \\
\hline \multirow[t]{2}{*}{$30-34$} & 0.188 & 0.597 & 0.303 & 0.005 \\
\hline & $(0.004) * * *$ & $(0.000) * * *$ & $(0.000)^{* * *}$ & $(0.001)^{* * *}$ \\
\hline \multirow[t]{2}{*}{$35-39$} & 0.184 & 0.592 & 0.347 & 0.005 \\
\hline & $(0.011)^{* *}$ & $(0.000)^{* * *}$ & $(0.000)^{* * *}$ & $(0.008)^{* * *}$ \\
\hline \multirow[t]{2}{*}{$40-44$} & 0.158 & 0.658 & 0.349 & 0.004 \\
\hline & $(0.049)^{* *}$ & $(0.000) * * *$ & $(0.000)^{* * *}$ & $(0.125)$ \\
\hline \multirow[t]{2}{*}{$45-54$} & 0.151 & 0.612 & 0.367 & -0.003 \\
\hline & $(0.071)^{*}$ & $(0.000)^{* * *}$ & $(0.000)^{* * *}$ & $(0.31)$ \\
\hline \multirow[t]{2}{*}{$55-$} & 0.396 & 0.861 & 0.632 & 0.003 \\
\hline & $(0.000)^{* * *}$ & $(0.000) * * *$ & $(0.000)^{* * *}$ & $(0.664)$ \\
\hline \multicolumn{5}{|l|}{ Education } \\
\hline \multirow[t]{2}{*}{ High school } & 0.239 & 0.118 & 0.212 & 0.005 \\
\hline & $(0.000)^{* * *}$ & $(0.026)^{* *}$ & $(0.000) * * *$ & $(0.000) * * *$ \\
\hline \multirow[t]{2}{*}{$<3$ years tertiary } & 0.499 & 0.268 & 0.455 & 0.014 \\
\hline & $(0.000)^{* * *}$ & $(0.000)^{* * *}$ & $(0.000) * * *$ & $(0.000)^{* * *}$ \\
\hline \multirow[t]{2}{*}{$>3$ years tertiary } & 0.575 & 0.309 & 0.527 & 0.018 \\
\hline & $(0.000)^{* * *}$ & $(0.000) * * *$ & $(0.000) * * *$ & $(0.000)^{* * *}$ \\
\hline \multicolumn{5}{|l|}{ Income } \\
\hline \multirow[t]{2}{*}[122,000-199,999]{} & -0.123 & 0.314 & -0.13 & -0.001 \\
\hline & $(0.001)^{* * *}$ & $(0.000) * * *$ & $(0.001)^{* * *}$ & $(0.303)$ \\
\hline \multirow[t]{2}{*}[200,000-299,999]{} & -0.265 & 0.621 & -0.284 & -0.009 \\
\hline & $(0.000)^{* * *}$ & $(0.000) * * *$ & $(0.000)^{* * *}$ & $(0.000)^{* * *}$ \\
\hline \multirow[t]{2}{*}[300,000-499,999]{} & -0.158 & 0.729 & -0.185 & -0.011 \\
\hline & $(0.043)^{* *}$ & $(0.000) * * *$ & $(0.017)^{* *}$ & $(0.000) * * *$ \\
\hline \multirow[t]{2}{*}[500,000-]{} & 0.106 & 0.911 & 0.073 & 0.002 \\
\hline & $(0.473)$ & $(0.000) * * *$ & $(0.62)$ & $(0.791)$ \\
\hline \multicolumn{5}{|l|}{ Wealth } \\
\hline \multirow[t]{2}{*}[200,000-499,999]{} & -0.282 & -0.835 & -0.29 & 0.002 \\
\hline & $(0.000)^{* * *}$ & $(0.000) * * *$ & $(0.000) * * *$ & $(0.718)$ \\
\hline \multirow[t]{2}{*}[500,000-1,499,999]{} & -0.039 & -0.961 & -0.053 & 0.018 \\
\hline & $(0.788)$ & $(0.000) * * *$ & $(0.714)$ & $(0.058)^{*}$ \\
\hline
\end{tabular}

Continued on the next page 
Continued from the previous page

\begin{tabular}{|c|c|c|c|c|}
\hline \multicolumn{5}{|l|}{ Year } \\
\hline \multirow[t]{2}{*}{1990} & 0.227 & 0.363 & 0.22 & 0.014 \\
\hline & $(0.000) * * *$ & $(0.000) * * *$ & $(0.000)^{* * *}$ & $(0.000)^{* * *}$ \\
\hline \multirow[t]{2}{*}{1995} & -1.81 & -2.394 & -1.833 & -0.047 \\
\hline & $(0.000) * * *$ & $(0.000) * * *$ & $(0.000)^{* * *}$ & $(0.000)^{* * *}$ \\
\hline \multirow[t]{2}{*}{2000} & -1.857 & -2.54 & -1.89 & -0.053 \\
\hline & $(0.000) * * *$ & $(0.000)^{* * *}$ & $(0.000)^{* * *}$ & $(0.000) * * *$ \\
\hline \multirow[t]{2}{*}{2004} & -2.177 & -2.919 & -2.214 & -0.062 \\
\hline & $(0.000)^{* * *}$ & $(0.000)^{* * *}$ & $(0.000)^{* * *}$ & $(0.000)^{* * *}$ \\
\hline \multicolumn{5}{|l|}{ Spouse } \\
\hline \multicolumn{5}{|l|}{ Age } \\
\hline \multirow[t]{2}{*}{$25-29$} & 0.984 & 0.52 & 0.67 & 0.01 \\
\hline & $(0.000)^{* * *}$ & $(0.000)^{* * *}$ & $(0.000)^{* * *}$ & $(0.000) * * *$ \\
\hline \multirow[t]{2}{*}{$30-34$} & 1.273 & 0.719 & 0.918 & 0.017 \\
\hline & $(0.000)^{* * *}$ & $(0.000) * * *$ & $(0.000)^{* * *}$ & $(0.000)^{* * *}$ \\
\hline \multirow[t]{2}{*}{$35-39$} & 1.651 & 0.902 & 1.23 & 0.028 \\
\hline & $(0.000)^{* * *}$ & $(0.000)^{* * *}$ & $(0.000)^{* * *}$ & $(0.000) * * *$ \\
\hline \multirow[t]{2}{*}{$40-44$} & 1.927 & 1.072 & 1.47 & 0.04 \\
\hline & $(0.000) * * *$ & $(0.000)^{* * *}$ & $(0.000)^{* * *}$ & $(0.000)^{* * *}$ \\
\hline \multirow[t]{2}{*}{$45-54$} & 2.3 & 1.374 & 1.825 & 0.06 \\
\hline & $(0.000)^{* * *}$ & $(0.000)^{* * *}$ & $(0.000)^{* * *}$ & $(0.000) * * *$ \\
\hline \multirow[t]{2}{*}{$55-$} & 3.087 & 2.056 & 2.59 & 0.11 \\
\hline & $(0.000)^{* * *}$ & $(0.000)^{* * *}$ & $(0.000)^{* * *}$ & $(0.000)^{* * *}$ \\
\hline \multicolumn{5}{|l|}{ Education } \\
\hline \multirow[t]{2}{*}{ High school } & 0.074 & 0.481 & 0.204 & 0.003 \\
\hline & $(0.074)^{*}$ & $(0.000) * * *$ & $(0.000)^{* * *}$ & $(0.010)^{* *}$ \\
\hline \multirow[t]{2}{*}{$<3$ years tertiary } & 0.216 & 0.615 & 0.34 & 0.007 \\
\hline & $(0.000) * * *$ & $(0.000)^{* * *}$ & $(0.000)^{* * *}$ & $(0.000) * * *$ \\
\hline \multirow[t]{2}{*}{$>3$ years tertiary } & 0.361 & 0.775 & 0.491 & 0.018 \\
\hline & $(0.000) * * *$ & $(0.000)^{* * *}$ & $(0.000)^{* * *}$ & $(0.000)^{* * *}$ \\
\hline \multicolumn{5}{|l|}{ Income } \\
\hline \multirow[t]{2}{*}[122,000-199,999]{} & 0.17 & 0.107 & 0.141 & 0.005 \\
\hline & $(0.000)^{* * *}$ & $(0.034)^{* *}$ & $(0.000)^{* * *}$ & $(0.000)^{* * *}$ \\
\hline \multirow[t]{2}{*}[200,000-299,999]{} & 0.575 & 0.677 & 0.601 & 0.02 \\
\hline & $(0.000)^{* * *}$ & $(0.000)^{* * *}$ & $(0.000) * * *$ & $(0.000)^{* * *}$ \\
\hline \multirow[t]{2}{*}[300,000-499,999]{} & 1.097 & 1.311 & 1.142 & 0.032 \\
\hline & $(0.000) * * *$ & $(0.000)^{* * *}$ & $(0.000)^{* * *}$ & $(0.000) * * *$ \\
\hline \multirow[t]{2}{*}[500,000-]{} & 2.11 & 2.403 & 2.162 & 0.091 \\
\hline & $(0.000)^{* * *}$ & $(0.000) * * *$ & $(0.000) * * *$ & $(0.000) * * *$ \\
\hline
\end{tabular}

Continued on the next page 
Continued from the previous page

\begin{tabular}{|c|c|c|}
\hline \multicolumn{3}{|l|}{ Male } \\
\hline \multicolumn{3}{|l|}{ Age } \\
\hline \multirow[t]{2}{*}{$25-29$} & 0.228 & 0.002 \\
\hline & $(0.054)^{*}$ & $(0.276)$ \\
\hline \multirow[t]{2}{*}{$30-34$} & 0.164 & 0.002 \\
\hline & $(0.173)$ & $(0.241)$ \\
\hline \multirow[t]{2}{*}{$35-39$} & 0.031 & 0.002 \\
\hline & $(0.803)$ & $(0.36)$ \\
\hline \multirow[t]{2}{*}{$40-44$} & 0.014 & 0.006 \\
\hline & $(0.917)$ & $(0.057)^{*}$ \\
\hline \multirow[t]{2}{*}{$45-54$} & -0.126 & 0.012 \\
\hline & $(0.33)$ & $(0.001)^{* * *}$ \\
\hline \multirow[t]{2}{*}{ 55- } & -0.225 & 0.012 \\
\hline & $(0.118)$ & $(0.079)^{*}$ \\
\hline \multicolumn{3}{|l|}{ Education } \\
\hline \multirow[t]{2}{*}{ High school } & -0.047 & -0.003 \\
\hline & $(0.491)$ & $(0.062)^{*}$ \\
\hline \multirow[t]{2}{*}{$<3$ years tertiary } & -0.118 & -0.008 \\
\hline & $(0.148)$ & $(0.000) * * *$ \\
\hline \multirow[t]{2}{*}{$>3$ years tertiary } & -0.129 & -0.008 \\
\hline & (0.104) & $(0.001)^{* * *}$ \\
\hline \multicolumn{3}{|l|}{ Income } \\
\hline \multirow[t]{2}{*}[122,000-199,999]{} & 0.444 & 0.007 \\
\hline & $(0.000)^{* * *}$ & $(0.000)^{* * *}$ \\
\hline \multirow[t]{2}{*}[200,000-299,999]{} & 0.913 & 0.022 \\
\hline & $(0.000)^{* * *}$ & $(0.000)^{* * *}$ \\
\hline \multirow[t]{2}{*}[300,000-499,999]{} & 0.955 & 0.023 \\
\hline & $(0.000)^{* * *}$ & $(0.000)^{* * *}$ \\
\hline \multirow[t]{2}{*}[500,000-]{} & 0.921 & 0.011 \\
\hline & $(0.000)^{* * *}$ & $(0.21)$ \\
\hline \multicolumn{3}{|l|}{ Wealth } \\
\hline \multirow[t]{2}{*}[200,000-499,999]{} & -0.541 & -0.021 \\
\hline & $(0.000)^{* * *}$ & $(0.000)^{* * *}$ \\
\hline \multirow[t]{2}{*}[500,000-1,499,999]{} & -0.893 & -0.035 \\
\hline & $(0.000)^{* * *}$ & $(0.001)^{* * *}$ \\
\hline \multicolumn{3}{|l|}{ Year } \\
\hline \multirow[t]{2}{*}{1990} & -0.534 & 0.013 \\
\hline & $(0.000)^{* * *}$ & $(0.000)^{* * *}$ \\
\hline \multirow[t]{2}{*}{1995} & -0.591 & 0.014 \\
\hline & $(0.000) * * *$ & $(0.000)^{* * *}$ \\
\hline \multirow[t]{2}{*}{2000} & -0.627 & 0.018 \\
\hline & $(0.000)^{* * *}$ & $(0.000)^{* * *}$ \\
\hline \multirow[t]{2}{*}{2004} & 0.15 & 0.005 \\
\hline & $(0.019) * *$ & $(0.044)^{* *}$ \\
\hline
\end{tabular}

Continued on the next page 
Continued from the previous page

\begin{tabular}{|c|c|c|c|c|}
\hline \multicolumn{5}{|l|}{ Spouse Age } \\
\hline $25-29$ & & & & $\begin{array}{c}-0.003 \\
(0.030)^{* *}\end{array}$ \\
\hline $30-34$ & & & & $\begin{array}{c}-0.006 \\
(0.001)^{* * *}\end{array}$ \\
\hline $35-39$ & & & & $\begin{array}{c}-0.014 \\
(0.000)^{* * *}\end{array}$ \\
\hline $40-44$ & & & & $\begin{array}{c}-0.022 \\
(0.000)^{* * *}\end{array}$ \\
\hline $45-54$ & & & & $\begin{array}{c}-0.035 \\
(0.000)^{* * *}\end{array}$ \\
\hline $55-$ & & & & $\begin{array}{c}-0.07 \\
(0.000)^{* * *}\end{array}$ \\
\hline \multicolumn{5}{|l|}{ Spouse Education } \\
\hline High school & & & & $\begin{array}{c}0.004 \\
(0.019)^{* *}\end{array}$ \\
\hline$<3$ years tertiary & & & & $\begin{array}{c}0.004 \\
(0.083)^{*}\end{array}$ \\
\hline$>3$ years tertiary & & & & $\begin{array}{l}-0.003 \\
(0.236)\end{array}$ \\
\hline Spouse Income & & & & \\
\hline$[122,000-199,999]$ & & & & $\begin{array}{l}-0.002 \\
(0.352)\end{array}$ \\
\hline$[200,000-299,999]$ & & & & $\begin{array}{c}-0.012 \\
(0.000)^{* * *}\end{array}$ \\
\hline$[300,000-499,999]$ & & & & $\begin{array}{c}-0.015 \\
(0.000)^{* * *}\end{array}$ \\
\hline$[500,000-]$ & & & & $\begin{array}{c}-0.021 \\
(0.043) * *\end{array}$ \\
\hline Male & & & $\begin{array}{c}-0.473 \\
(0.000)^{* * *}\end{array}$ & $\begin{array}{c}-0.008 \\
(0.000)^{* * *}\end{array}$ \\
\hline Constant & $\begin{array}{c}-5.129 \\
(0.000)^{* * *} \\
\end{array}$ & $\begin{array}{c}-5.517 \\
(0.000) * * * \\
\end{array}$ & $\begin{array}{c}-4.919 \\
(0.000) * * * \\
\end{array}$ & $\begin{array}{c}0.009 \\
(0.000)^{* * *}\end{array}$ \\
\hline$N$ & 171187 & 170464 & 341651 & 341651 \\
\hline $\mathrm{R}^{2} /$ Pseudo- $\mathrm{R}^{2}$ & 0.141 & 0.141 & 0.146 & 0.041 \\
\hline
\end{tabular}

